\title{
Pressure and velocity behavior of an incompressible flow through the reduction of a pipe using CFD
}

Mtro. Eliel Eduardo Montijo Valenzuela1 ${ }^{1}$ Mtro. Francisco Alan Espinoza Zallas², Mtro. Rogelio Acedo Ruiz ${ }^{3}$, Mtro. Elvis Osiel Covarrubias Burgos ${ }^{4}$, Dr. Pedro Jancarlo Gomez Vega $^{5}$

1 eliel.montijo@ues.mx.ORCID: 0000-0001-8538-0767.Universidad Estatal de Sonora

2 alan.espinoza@ues.mx. ORCID: 0000-0002-1177-2028. Universidad Estatal de Sonora.

${ }^{3}$ rogelio.acedor@ hermosillo.tecnm.mx. ORCID: 0000-0001-6643-5670. Instituto Tecnológico de Hermosillo 4 elvisosiel13@gmail.com. ORCID: 0000-0003-4548-5243. Instituto Tecnológico de Hermosillo 5 pedro.gomez@unison.mx. ORCID: 0000-0001-5641-872X. Universidad de Sonora

DOI 10.46589/rdiasf.vi35.403

Recibido 5 de abril 2021.

Aceptado 5 de junio 2021

Publicado 30 de junio de 2021

\section{Resumen}

En esta investigación se plantea la metodología para la simulación mediante fluidodinámica computacional (del inglés CFD-Computational Fluid Dynamics) de un flujo incompresible mediante Solidworks ${ }^{\circledR}$ Flow Simulation, con la finalidad de medir el comportamiento de la presión y la velocidad en reducciones del área transversal de la tubería, haciendo decrementos de $0.02 \mathrm{~m}$ en el área de entrada de cinco modelos diferentes. La metodología está planteada en tres partes principales; el diseño bidimensional asistido por computadora CAD (del inglés ComputerAided Design) de la tubería, el modelado de la tubería y la simulación con CFD. Los resultados de simulación, arrojaron un incremento de entre el 10 y el 14\% de la velocidad del fluido, y una pérdida de presión de 13 a 75\% en la zona de menor área de la tubería por cada $0.02 \mathrm{~m}$ de reducción en el diámetro, derivado del principio de conservación de la energía de los fluidos ideales.

Palabras Clave: Dinámica de fluidos; presión; principio de conservación de la energía.

1 Los contenidos de este articulo están bajo una licencia de Creative Commons Atribución No Comercial - Sin Obra Deriva da 4.0 Internacional 


\begin{abstract}
In this research the methodology for the simulation by computational fluid dynamics (CFDComputational Fluid Dynamics) of an incompressible flow is proposed by using Solidworks® Flow Simulation, measuring the behavior of pressure and velocity in reductions of the crosssectional area of the pipe, making decrements of $0.02 \mathrm{~m}$ in the input area of five different models. There are three main parts to this methodology; two-dimensional computer-aided CAD (Computer-Aided Design) design of the pipeline, pipeline modeling, and CFD simulation. The simulation results showed an increase of between 10 and $14 \%$ of the fluid velocity, and a pressure loss of 13 to $75 \%$ in the area with the smallest area of the pipe for each $0.02 \mathrm{~m}$ reduction in diameter, derived from the energy conservation principle of ideal fluids.
\end{abstract}

Key words: Fluid dynamics; pressure; energy conservation principle.

\title{
1. Introduction
}

The part of mechanics that studies the behavior of gases and liquids is known as fluid mechanics (Velázquez, 2016), being hydrodynamics, the one that studies the behavior of liquids in motion (Pérez, 2016). In (Álvarez et al, 2018), fluids are classified considering two of their basic properties; compressibility and viscosity. Compressibility is the change in volume that a substance experiences when a pressure change is applied (Zacarías et al., 2017), and the subclassification of fluids for this property are compressible and incompressible fluids. In the case of incompressible fluids, which includes liquids, the proximity between their molecules prevents pressure changes from affecting their density considerably, that is not the case of compressible fluids that include gases, the Intermolecular distances are so wide that the interaction forces are very weak, causing considerable changes in density when pressure is applied to them (Arias et al., 2017). 
In hydrodynamics, the study of Bernoulli's principle is important, since it establishes the conservation of energy in ideal fluids. In (Águeda et al., 2019) the Bernoulli principle is described as the behavior of a flow in motion along a stream line, assuming that the flow is ideal, that means it does not present viscosity or friction, in circulation regime of a closed control volume.

The principle shows that static and dynamic pressure can be exchanged in the flow field, so that in cross sections where the velocity increases, the static pressure can be low, or vice versa.

The importance of the study of fluid mechanics is fundamental in a diversity of fields, especially in the engineering area, such as aeronautical engineering, industrial engineering, biomedical engineering, civil engineering, chemical engineering, among others. (Herrera et al., 2018). It can be applied to the development and innovation of transport technology applications, such as airplanes or cars, the study of drugs in the bloodstream, or the design of robotic systems used in the industry, to more common applications, but no less complex, such as the design of containers to store liquids, greenhouse irrigation systems, or the design of the public drinking water supply network.

The design of pipes plays an important role in the transport of fluids (liquid or gaseous), and gives meaning to many of the applications mentioned above. In the design of pipes, there are some important parameters that determine the correct operation of these devices, among them, the operating variables and the physical properties of the fluid, such as the mass flow, pressure, speed and density of the fluid (Manzano et al, 2014). Manufacturing considerations are essential for the performance of the pipes according to their application, using appropriate materials for the process, in addition to the mechanical calculations necessary to guarantee their quality and safety during their operating lifetime, using international standards such as the ASME standard. (American Society of Mechanical Engineers) according to Sakharkar et al., (2018).

On the engineering side, for the validation of pipes and their elements, CFD computational tools are currently used to accurately forecast the behavior of the fluid when it is in operation. 
CFDs consist of the analysis of systems related to fluid flow, heat transfer and other associated phenomena (such as chemical reactions) through computer simulation (Bahamón \& Quintana, 2009). These studies include the simulation of incompressible flow in pipe fittings for the loss of head calculation (Jines, 2017), cavitation analysis from pressure wave propagations (Nohmi, 2019) and the modeling of pipes for applications with gas flow (Sami \& Turz, 2020), to name a few.

In this research, the CFD tool is used to determine the changes in the velocity and pressure of a compressible fluid within a stream line with changes in diameter in the cross section, in order to be able to predict abnormal behavior of the flow within the pipeline.

\section{Methodology}

The methodology is divided in three main parts; Two-dimensional CAD pipe design, pipe modeling and CFD simulation. This methodology is used in Montijo \& Ramírez (2017), a computer, Solidworks ${ }^{\circledR}$ software and the Solidworks ${ }^{\circledR}$ Flow Simulation complement for CFD are required as materials (the version 2018 is used on the program and the complement).

\subsection{Two-dimensional CAD design of the pipeline.}

For the purposes of this investigation, a pipe with different cross-sectional areas is presented. One half of a contour delimited by lines and fillets, made with sketch features in Solidworks®, is made. 5 CAD designs are made with dimensional change in the area of minor diameter.

\subsection{Three-dimensional modeling of the pipe.}

With the contour, the three-dimensional model of the pipe is made. To do this, enter the operations tab from the Solidworks ${ }^{\circledR}$ interface and choose the revolution operation, selecting the longest axis as the axis of revolution. Subsequently, the shelf operation is chosen, with a laminar wall thickness equivalent to $0.01 \mathrm{~m}$, allowing the piece to be hollow. 5 models are made, subject to the dimensional changes of the previous section. 
Año 14 / Núm. 35 / Enero-junio 2021

Revista de Investigación Académica sin Frontera

ISSN 2007-8870

\subsection{CFD Analysis with Solidworks® Flow Simulation Plug-in}

For this section, the steps to follow will be listed for simulation purposes.

a) Delimitation of the control volume. The three-dimensional models generated must have a control volume, the main requirement to be able to execute a CFD study.

b) We open Solidworks® Flow Simulation from the complements section.

c) We initialize a new project from the Solidworks® Flow Simulation plug-in.

d) We delimit the input and output conditions of the system to be simulated. For this study, a mass flow rate of $0.06 \mathrm{~m} 3 / \mathrm{s}$ was applied to all models at the inlet (internal face of the smaller area section) and a pressure of 1 atmosphere (atm) at the outlet of the system (internal face of the section of the larger area). The flow that is simulated is water in a laminar regime.

e) Once the system is defined, the simulation goals are integrated. For this case, the minimum and maximum speed in the three coordinate axes $(\mathrm{x}, \mathrm{y}, \mathrm{z})$ and the total pressure of the system are selected.

f) Later, the meshing is defined. Solidworks ${ }^{\circledR}$ Flow Simulation technology uses meshes based on Cartesian coordinates, and since it is a simulation of simple geometry, the methodology used by Sobachkin \& Dumnov (2014) is used, using standard mesh values.

g) The analysis is run.

h) The results obtained from CFDs are displayed and analyzed, in section X. 


\section{Results}

The design of the pipe in 2 dimensions is presented in figure 1a. All measurements are constant, except for the dimension marked in X, and the units are in the MKS system (meter-kilogramsecond). In Figure 1b, the solid model is presented in isometric divided in half by the lateral view plane, with the intention that the laminar wall is visualized.

Table 1 shows the dimensions for the different sketches used for simulation, with the $\mathrm{X}$ dimension being variable in each experiment performed.

The simulation results for each model are presented below, where the changes in velocity are observed in the $\mathrm{X}$ coordinate axis, and the pressure changes in the system as area adjustments are made in section $X$.

In figure 2 they are compiled speed simulation results using a graph. Figure 3 shows the speed simulation results for the different models. In figures $3 a, 3 b, 3 c, 3 d$ and $3 e$, the velocity results are shown in the $X$ axis, for the geometries of $X=0.041 \mathrm{~m}, 0.039 \mathrm{~m}, 0.037 \mathrm{~m}, 0.035 \mathrm{~m}$ and 0.033 $\mathrm{m}$, respectively. Figure 4 shows the pressure simulation results for the different models. Figures $4 \mathrm{a}, 4 \mathrm{~b}, 4 \mathrm{c}, 4 \mathrm{~d}$ and $4 \mathrm{e}$ show the results of pressure changes, for the geometries of $\mathrm{X}=0.041 \mathrm{~m}$, $0.039 \mathrm{~m}, 0.037 \mathrm{~m}, 0.035 \mathrm{~m}$ and $0.033 \mathrm{~m}$, respectively. In figure 5 the speed simulation results are compiled using a graph. 


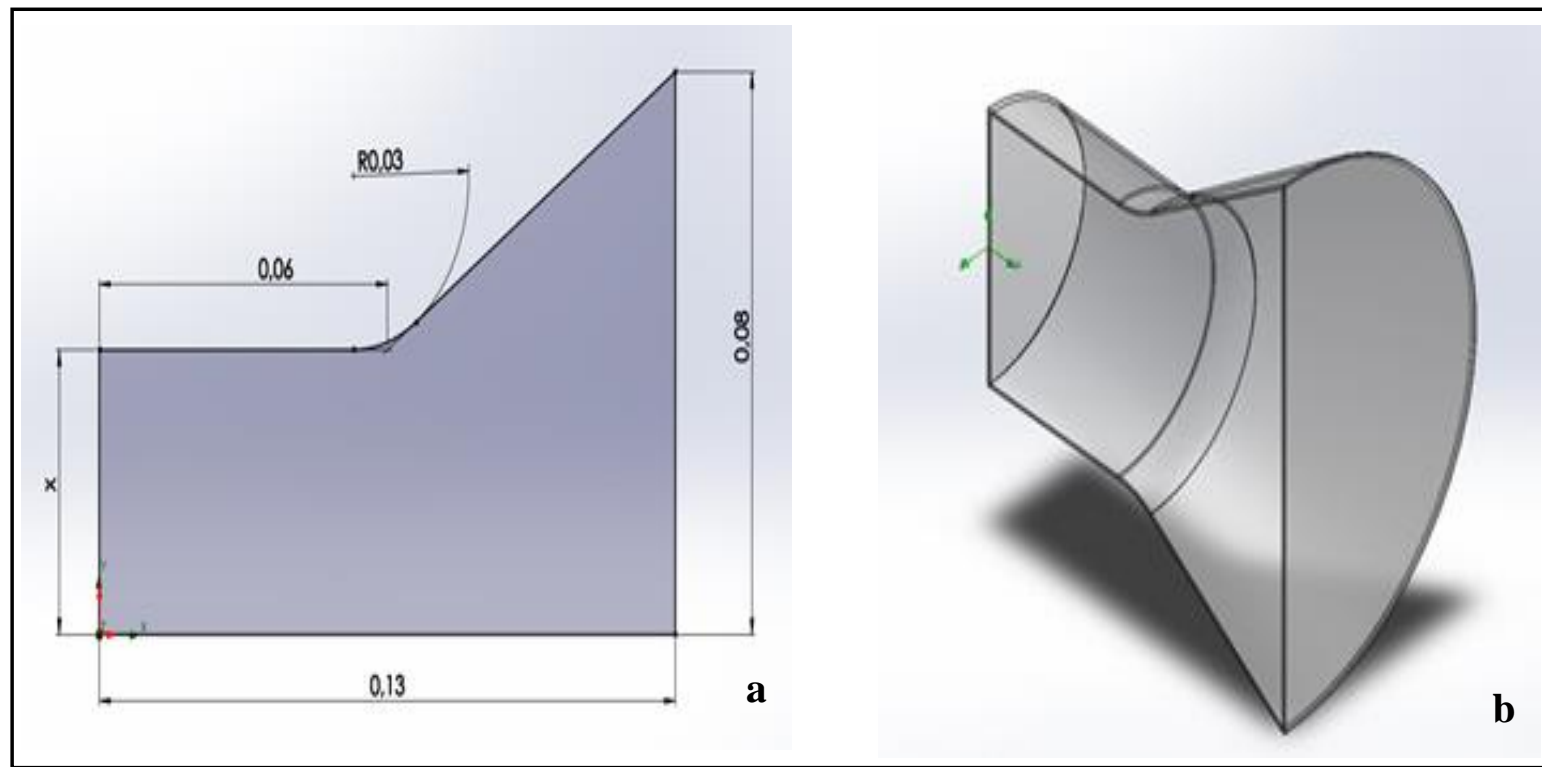

Figure 1. In a, the 2D pipe design (units in $\mathrm{m}$ ) is shown. In $\mathrm{b}$, the solid model is shown in isometric. Source: self made.

Table 1. Dimensional measurements of 2D pipe design.

\begin{tabular}{|l|l|}
\hline Número & $\mathbf{X}(\mathbf{m})$ \\
\hline 1 & 0.041 \\
\hline 2 & 0.039 \\
\hline 3 & 0.037 \\
\hline 4 & 0.035 \\
\hline 5 & 0.033 \\
\hline
\end{tabular}

* Only the $\mathrm{X}$ values change.

Source: self made. 
Año 14 / Núm. 35 / Enero-junio 2021

Revista de Investigación Académica sin Frontera ISSN 2007-8870

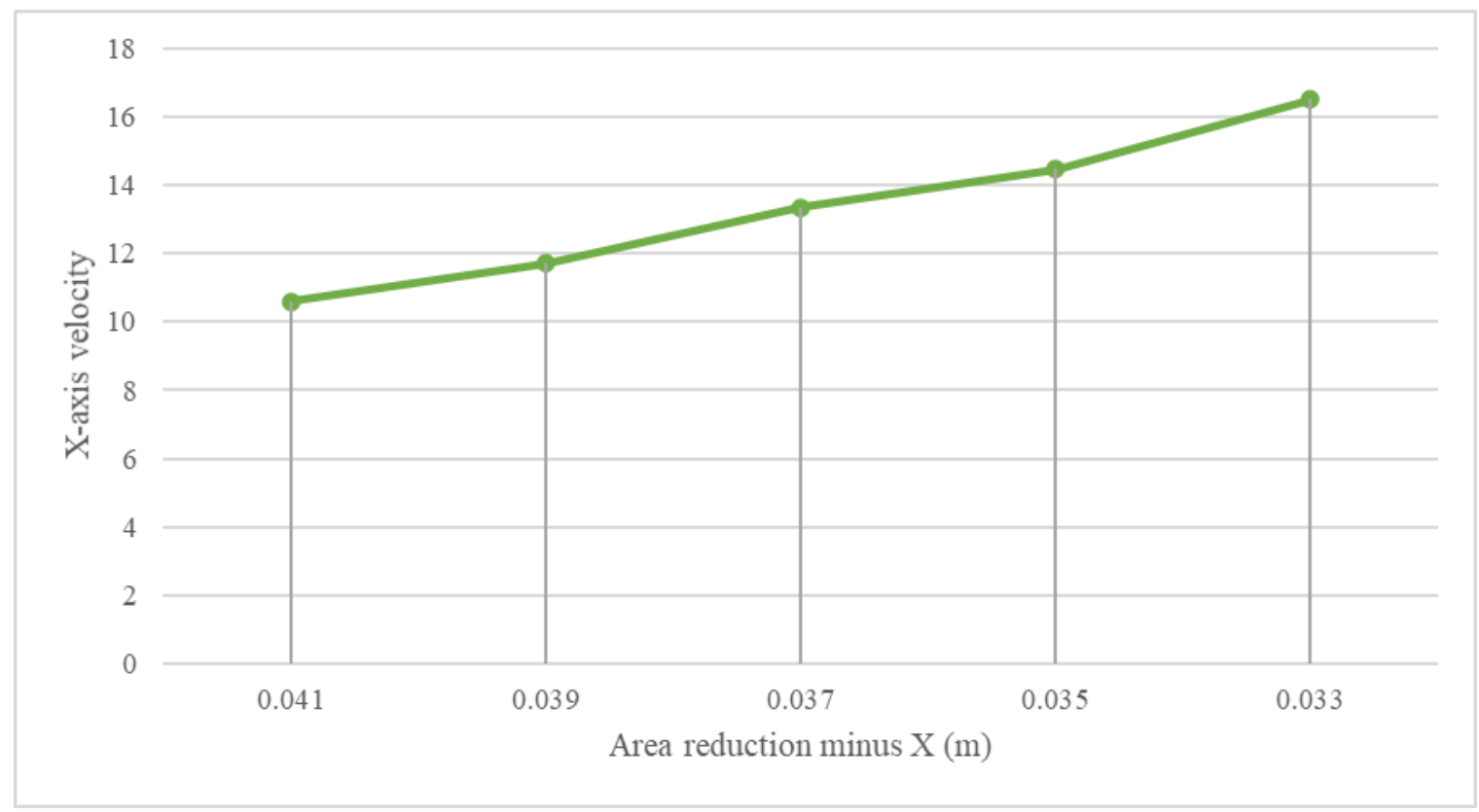

Figure 2. Speeds obtained in simulation, based on the diameter reductions of section X. Source: self made. 
Año 14 / Núm. 35 / Enero-junio 2021

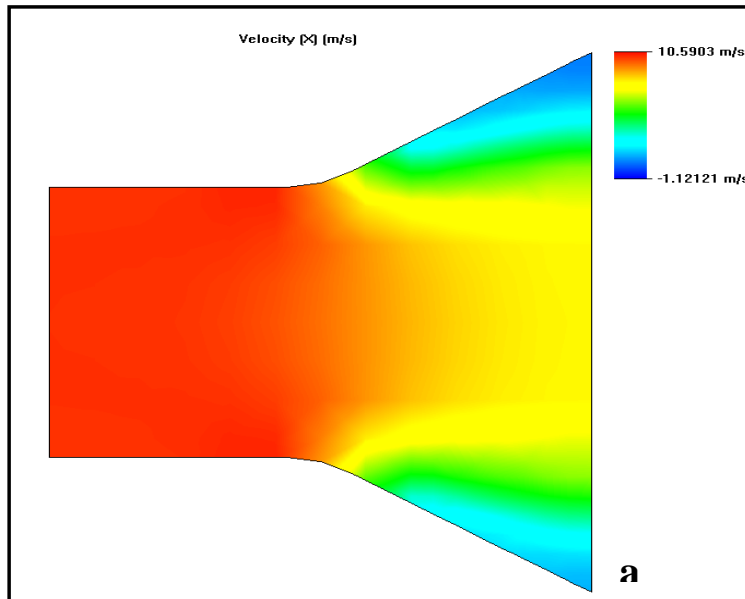

$\operatorname{Min}=-1.12121 \mathrm{~m} / \mathrm{s} \quad \operatorname{Max}=10.5903 \mathrm{~m} / \mathrm{s}$

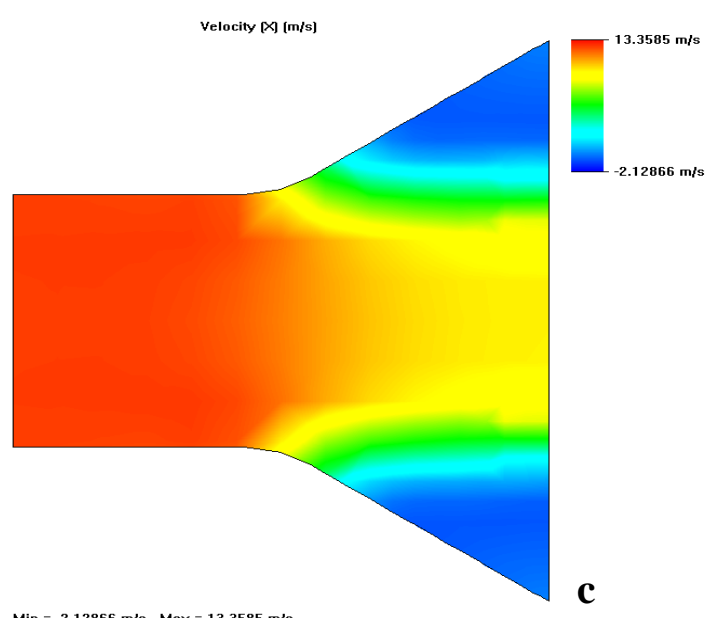

$\operatorname{Min}=-2.12866 \mathrm{~m} / \mathrm{s}$ Max $=13.3585 \mathrm{~m} / \mathrm{s}$

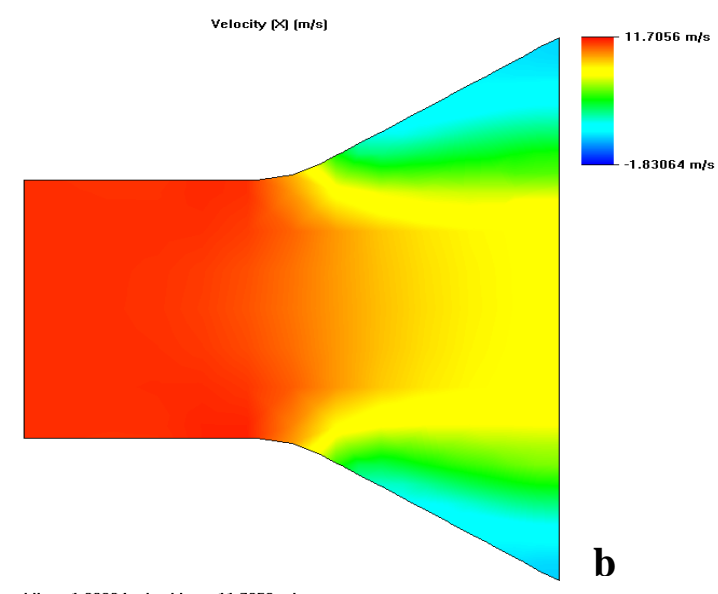

$\operatorname{Min}=-1.83064 \mathrm{~m} / \mathrm{s} \quad \operatorname{Max}=11.7056 \mathrm{~m} / \mathrm{s}$

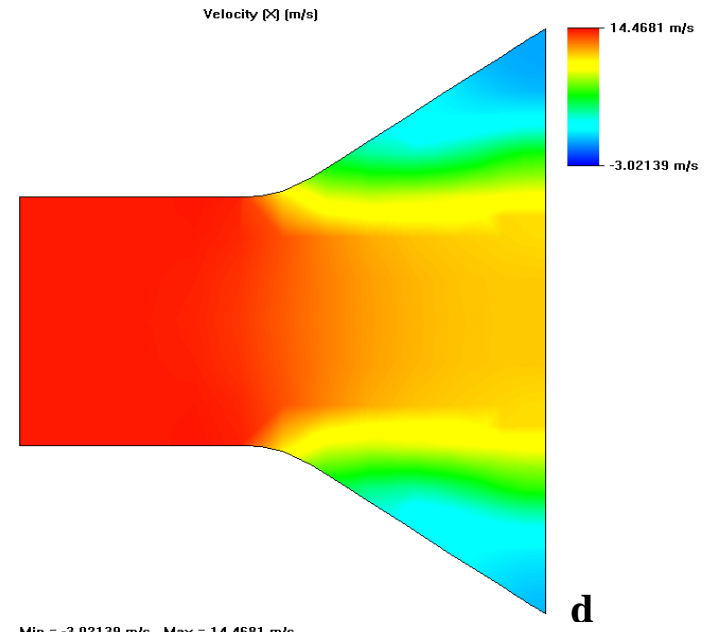

$\operatorname{Min}=-3.02139 \mathrm{~m} / \mathrm{s} \quad$ Max $=14.4681 \mathrm{~m} / \mathrm{s}$
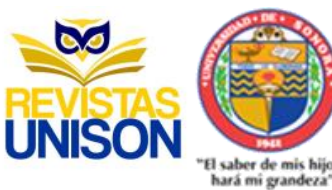

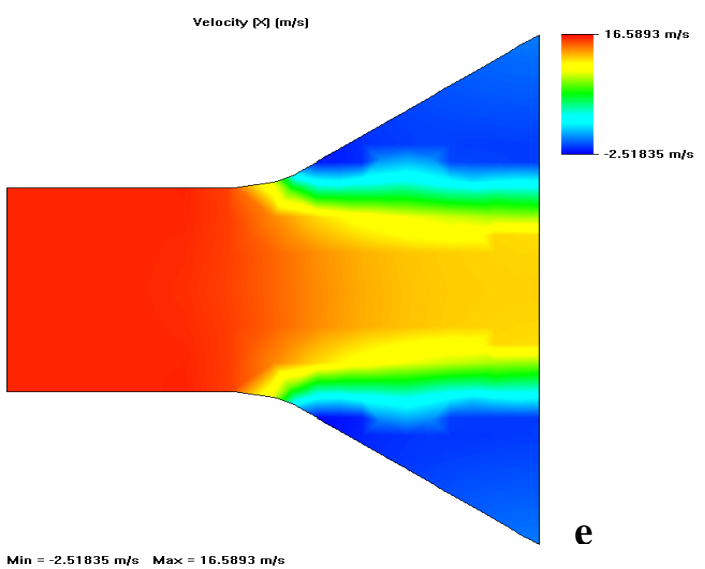




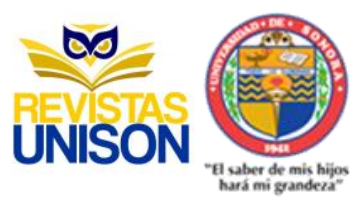

Figure 3. Speed simulation results. a) for $X=0.041 \mathrm{~m}, \mathrm{~b}$ ) for $\mathrm{X}=0.039 \mathrm{~m}, \mathrm{c}$ ) for $\mathrm{X}=0.037 \mathrm{~m}, \mathrm{~d}$ ) for $X=0.035 \mathrm{~m}$ and e) for $X=0.033 \mathrm{~m}$. Source: self made.

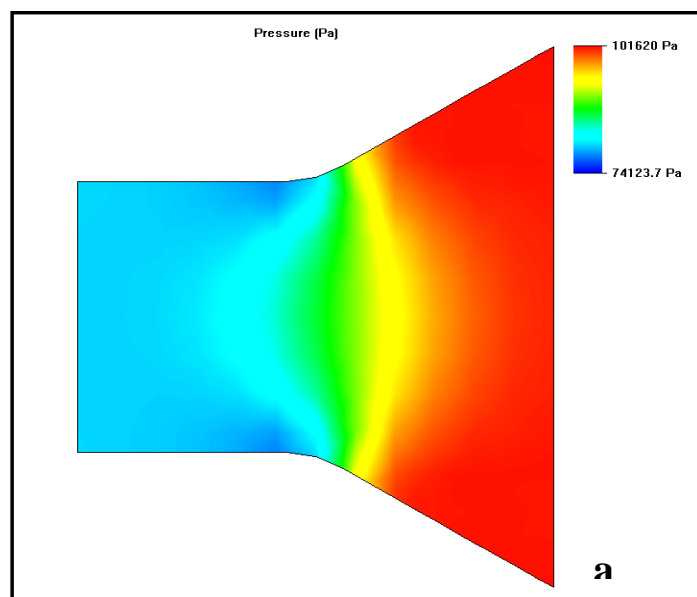

$\operatorname{Min}=74123.7 \mathrm{~Pa} \quad \operatorname{Max}=101620 \mathrm{~Pa}$

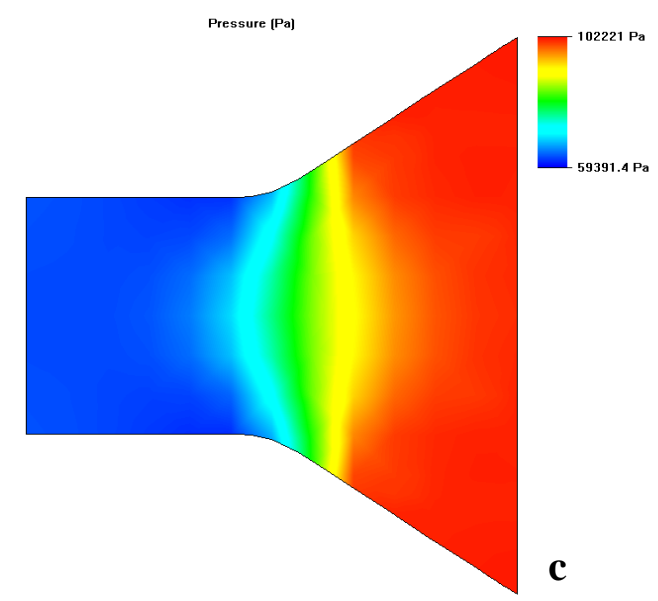

$\operatorname{Min}=59391.4 \mathrm{~Pa} \quad \operatorname{Max}=102221 \mathrm{~Pa}$

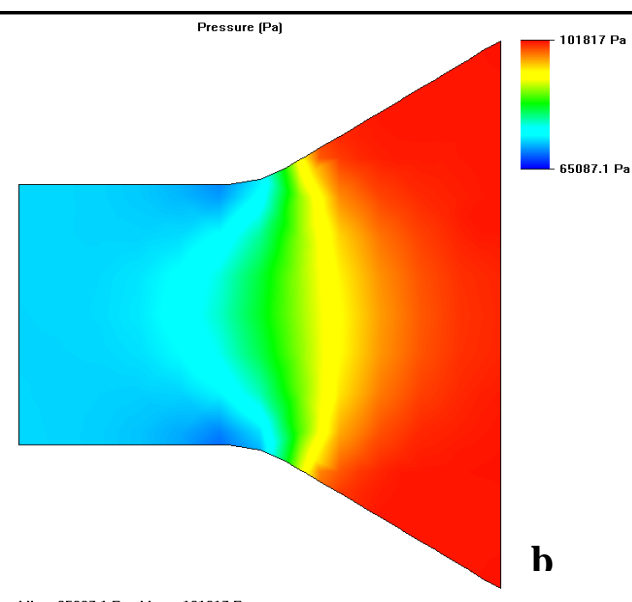

$\operatorname{Min}=65087.1 \mathrm{~Pa} \operatorname{Max}=101817 \mathrm{~Pa}$

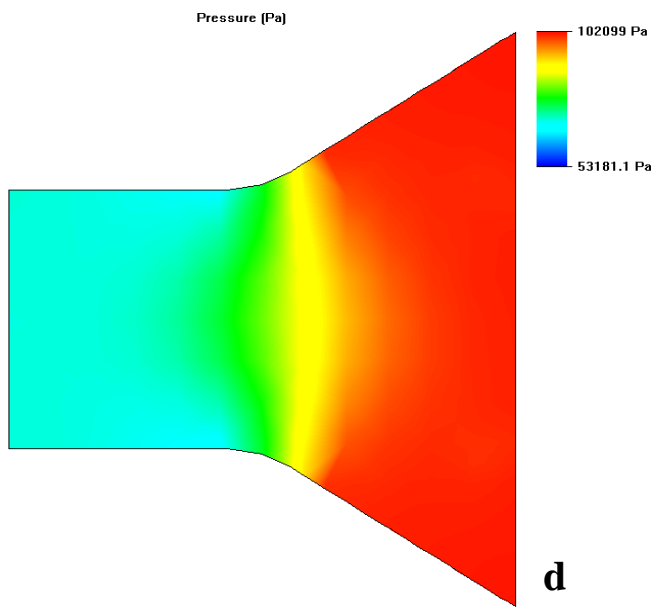

$\operatorname{Min}=53101.1 \mathrm{~Pa} \operatorname{Max}=102099 \mathrm{~Pa}$

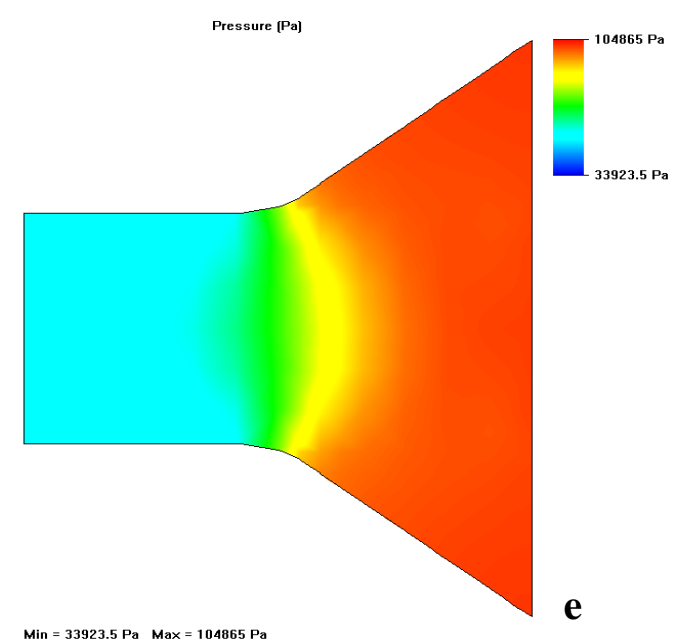

$\operatorname{Min}=33923.5$ 
Figure 4. Pressure simulation results. a) for $X=0.041 \mathrm{~m}, \mathrm{~b}$ ) for $X=0.039 \mathrm{~m}, \mathrm{c}$ ) for $\mathrm{X}=0.037 \mathrm{~m}$, d) for $X=0.035 \mathrm{~m}$ and e) for $X=0.033 \mathrm{~m}$. Source: self made.

The results obtained from the CFD simulations for pressure changes are shown graphically in figure 5 .

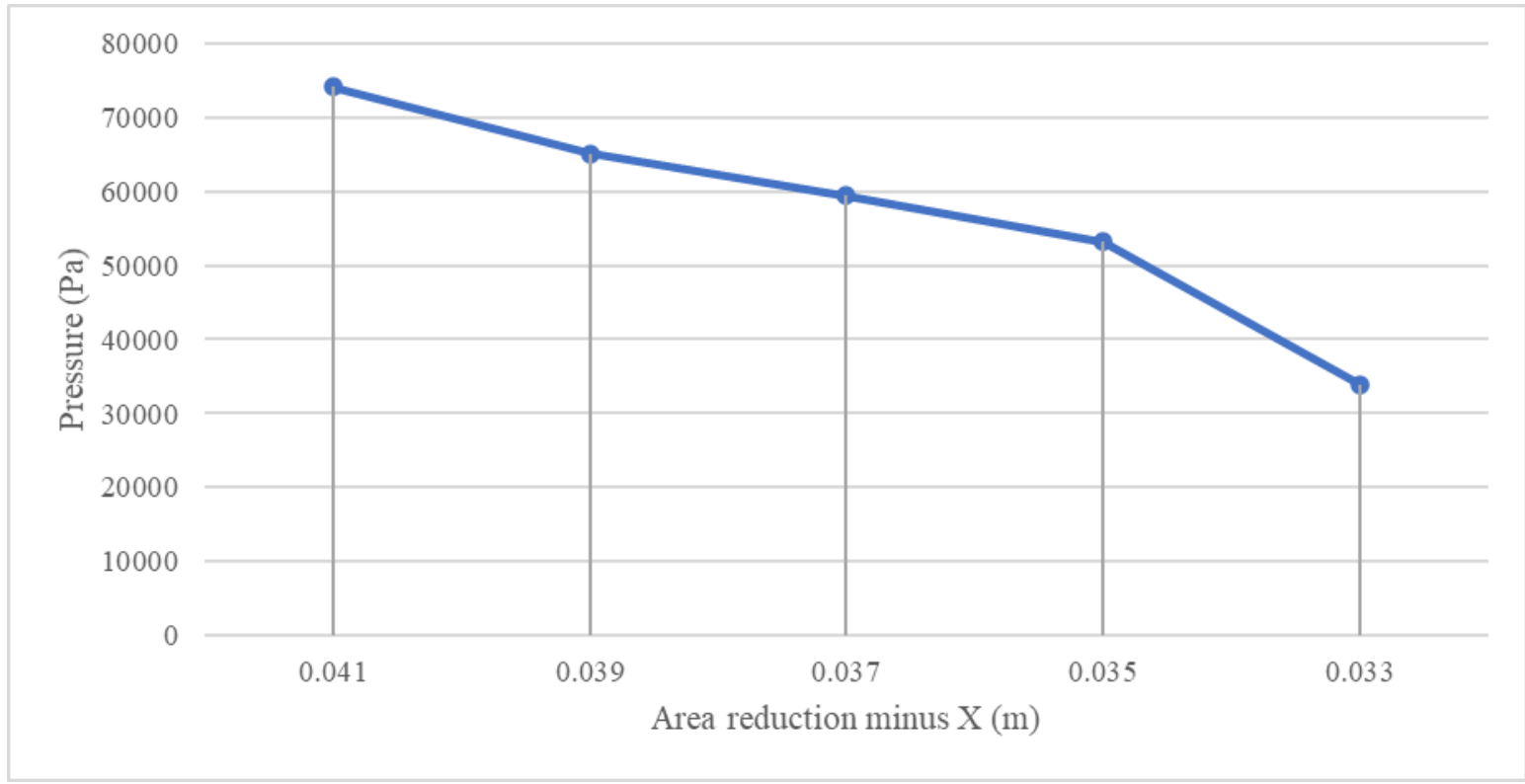

Figure 5. Pressures obtained in simulation, based on the diameter reductions of section $\mathrm{X}$. Source: self made.

\subsection{Results discussion}

The results of this research show that reductions in the cross-sectional area of a pipe generate speed increasement in flow lines, ranging from 10 to $14 \%$ for each decrease of $0.02 \mathrm{~m}$ in diameter. Regarding to the pressure within the system, the simulations register losses ranging from 13 to $75 \%$ for each decrease of $0.02 \mathrm{~m}$ in the diameter in the cross-sectional area of the pipe. 
The effects of velocity gain and fluid pressure loss in speed reduction were observed by (Diring et al., 2017; Carrillo, 2018; Toapanta et al., 2018; Cuscó et al., 2017), through CFD analysis techniques and analytics. In Cuscó et al., (2017), it is established that the pressure drop is caused by energy losses, that are originated by a sudden and / or gradual reduction in the cross section of the pipe (Toapanta et al., 2018). This phenomenon is associated with the Venturi effect (Diring et al., 2017), which is a particular case of Bernoulli's principle. It establishes that an ideal fluid, within a closed conduit, decreases its pressure when its speed increases when passing through a smaller sectional area, so talking in energetic terms of the energy conservation for ideal fluids, according to Bernoulli's principle, in high-speed flow through a constriction, the kinetic energy must be increased, in expense of energy pressure (Olmos \& Nave, 2018).

\section{Conclusions}

This paper presents the methodology to perform CFD analysis on closed pipes with different cross-sectional sections, using Solidworks® Flow Simulation 2018 software; specifically, pressure and velocity analysis for an ideal incompressible fluid (water).

A relationship was found between the reduction of the pipe with the speed and pressure of the fluid. The fluid velocity increased between 10 and 14\% in the smallest area of the pipe for every $0.02 \mathrm{~m}$ of reduction. As well, it was found that in the same area, there are pressure losses of 13 to $75 \%$ according to the CFD results. This phenomenon was associated with Bernoulli's principle, which states that, in the straits of a pipe the kinetic energy increases (represented as the speed of the fluid) and the pressure energy decreases.

CFD systems can predict abnormal behaviors within pipeline systems, which can be corrected from the design stage, in addition, the qualitative and quantitative analysis that this study shows, 
can be relevant in making decisions for the transportation of fluids. such as maintenance, pressure changes in critical areas, turbulence, and wear, to name a few.

For the application of this methodology in CFD simulation of real problems, the author recommends establishing all the input and output conditions and variables of the system, collected in the field (such as operating temperature, fluid viscosity, pipe material, coefficient of friction of the pipe, among others), to be added to the simulator and give more accurate and precise calculations.

\section{References}

Águeda, E., Gómez, T., Navarro, J. \& Martín, U. (2019). Sistemas de transmisión de fuerzas y trenes de rodaje. Paraninfo.

Álvarez, M., Parrales, E., Plúa, L., Gutiérrez, L., Parrales, C. \& Marcillo, G. (2018). Hidráulica aplicada para ingenieros civiles. 3 ciencias.

Arias, J., Riboux, G. \& Fernández, J. (2017). Introducción a la mecánica de fluidos. Paraninfo Universidad.

Bahamón, D. \& Quintana, G. (2009). “Simulación del patrón de flujo en fase simple para diferentes diseños de separadores ciclónicos", Revista Investigaciones Aplicadas, 45(5), 11-20.

Carrillo, V. (2018). "Experimental and numerical simulation as a calibration measure of a venturi tube", International Journal of Hydrology, 2(2). doi: 10.15406/ijh.2018.02.00071.

Cuscó, Y., Guardia, Y. \& Áreas, R. (2017). "Simulación del comportamiento de la presión en un sistema de riego por pivote central", Revista Granmense de Desarrollo Local, 1(3), 249260. 
Diring, A., Fromme, L., Petry, M. \& Weizel, E. (2017). "Comparison Between COMSOL Multiphysics ${ }^{\circledR}$ and STAR-CCM+® Simulation Results and Experimentally Determined Measured Data for a Venturi Tube", en Excerpt from the Proceedings of the 2017 COMSOL Conference in Rotterdam, Rotterdam, 1-6.

Herrera, Y., Bonnin, A. \& Serra, R. (2018). “Importancia de la mecánica de los fluidos en las carreras ingenieriles" en 9 Convención Científica de Ingeniería y Arquitectura, La Habana.

Jines, J. (2017). "Simulación de Flujo Incompresible y de una Fase en Accesorio de Tuberías (Codo $90^{\circ}$ de alto radio) mediante Dinámica de Fluidos Computacional (CFD), para Cálculo de Factor de Pérdida KL”, Revista Tecnológica ESPOL - RTE, 30(2), 56-74. Manzano, J., Azevedo, B., Bomfim, G., Royuela, A., Palau, C. \& Viana, T. (2014). “Diseño y predicción del funcionamiento de inyectores Venturi en riego localizado" $R B E A A, 18(12)$, 1209-1217. doi: 10.1590/1807-1929/agriambi.v18n12p1209-1217.

Montijo, E. \& Ramírez, F. (2017). “Aplicación de la ecuación de continuidad y análisis de elemento finito para el cálculo de velocidad de salida de un flujo permanente incompresible" Espacio ITH, 7(1), 14-19.

Nohmi, M., Kagawa, S., An, B., Tsuneda, T., Yokota, K. \& Kang, D. (2019). "Cavitation CFD analyses considering the pressure wave propagation within the piping systems", IOP Conference Series: Earth And Environmental Science, 240. doi: 10.1088/1755$1315 / 240 / 6 / 062025$.

Olmos, M. \& Nave, R. (2018). "Pressure", Hyperphysics.phy-astr.gsu.edu. Consultado en 02 enero 2020 en: http://hyperphysics.phy-astr.gsu.edu/hbase/pber.html. 
Pérez, H. (2016). Física 2. Grupo Editorial Patria.

Sakharkar, S., Khake, P. \& Kolambakar, V. (2018). “Overview of industrial piping structural design”, IJESRT, 7(2), 45-50. doi: 10.5281/zenodo.1165605.

Sami, N. \& Turz, Z. (2020). "Computational fluid dynamic (CFD) modelling of transient flow in the intermittent gas lift", Petroleum Research. doi: 10.1016/j.ptlrs.2020.03.001.

Sobachkin, A. \& Dumnov, G. (2014). "Numerical Basis of CAD-Embedded CFD”, en NAFEMS World Congress 2013 Salzburg, Austria, pp. 1-19.

Toapanta, L., Bohórquez, G., Caiza L. \& Quitiaquez, W. (2018). "Análisis numérico de los perfiles de velocidad de un flujo de agua a través de una tubería con reducción gradual", Enfoque UTE, 9(3), 80-92. Doi: http://dx.doi.org/10.29019/enfoqueute.v9n3.290 Velázquez, C. (2016). Mecánica vectorial para ingenieros. Estática. Palibrio.

Zacarías, A., González., J., Granados A. \& Mota, A. (2017). Mecánica de fluidos. Teoría con aplicaciones y modelado. Editorial Patria. 
Año 14 / Núm. 35 / Enero-junio 2021

- Dialnet

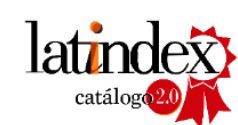

Iff IJIFACTOR

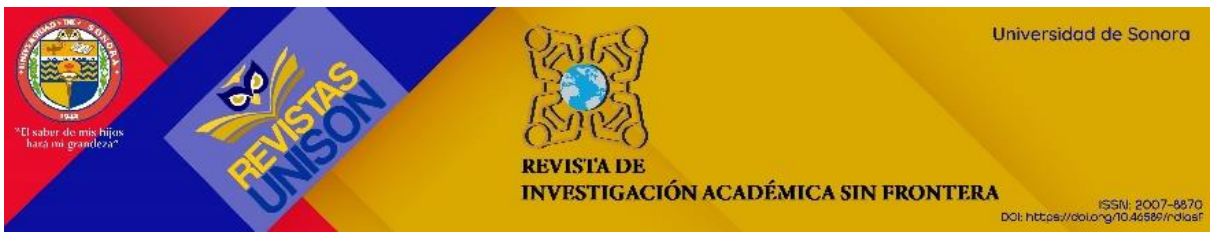

